\title{
David William Alexander Donald, OBE, TD
}

On 25th April 1986 the Faculty lost one of its most distinguished Fellows when David Donald passed away suddenly after an evening spent dining with golfing friends.

After leaving Dundee High School David enrolled as a student and completed the Faculty examinations before he was 21 . It was the start of a brilliant career. In his office he rose to the top position of general manager and in the Faculty he served as tutor, examiner, member of council, honorary editor and finally as President from 1969-71. He also served for many years as national correspondent for I.A.A. His contributions to actuarial literature were many and varied and his contributions to discussion at sessional meetings were often controversial but always thought-provoking. He will perhaps be best remembered as the author of the textbook on Compound Interest and Annuities Certain which has now been in use for over 30 years.

During the war David Donald rose from 2nd Lieutenant with the Black Watch to Lieutenant Colonel on the staff at General Headquarters, India. For his war service he was awarded the $\mathrm{OBE}$ and for service as a territorlal, the Territorlal Decoration.

Outside of business and professional activities he gave generously of his time and substance in public service and in work for church and charitable organisations.

David was good company for every occasion and he will be sadly missed by his many friends but he has well earned his rest and his place in the annals of the Faculty.

G. C. P 